\title{
NEW BUSINESS STRATEGIES FORMATION OF ENTERPRISES AND OUTSOURCING DEVELOPMENT AS A CONDITION FOR INCREASING COMPETITIVENESS IN THE MARKETS OF EUROPE AND UKRAINE: COMPARATIVE ANALYSIS
}

\author{
Svitlana Khalatur', Nataliia Kuprina², Larysa Kurbatska ${ }^{3}$
}

\begin{abstract}
The purpose of the article is to substantiate the need for the formation of new business strategies of enterprises and the development of outsourcing as a condition for increasing competitiveness in the markets of Europe and Ukraine. The subject of research is the process of forming new business strategies of enterprises and the development of outsourcing as a condition for increasing competitiveness in the markets of Europe and Ukraine. Methodology. Theoretical and methodological basis of the study is the theory of systems, the theory of economic development, scientific developments of foreign and domestic models on the business strategy formation of enterprises, economic development of European countries. General scientific and special methods were used to achieve a specific goal, in particular: the methods of economic and financial analysis; statistical and economic method, including comparison, as well as the graphical method. Conclusion. Thus, in the context of globalization, all countries and their businesses are looking for new forms of international cooperation, including outsourcing. The effectiveness of outsourcing business strategies is confirmed by global practice, which shows that currently more than half of European companies use outsourcing in their activities. There is a unique opportunity for Ukraine and its regions to take advantage of international outsourcing due to the possible positioning in today's market both as a provider of outsourcing services and as a customer. In the first case, this can be achieved through an attractive ratio of high skills and low wages, a satisfactory level of infrastructure development, and in the second case - by getting access to cheaper or rare resources, new technologies, best business practices, which forms the basis for the transition of Ukrainian enterprises to innovative development. Outsourcing is an effective way of doing business, given the benefits and opportunities that the customer company receives when using it. The business model of innovative outsourcing is an important direction of modern business development in the global marketplace. Nowadays, personnel outsourcing is an effective tool for improving the performance of any enterprise, taking into account the above-mentioned advantages and limitations that the customer receives in their application. However, outsourcing should not be considered a universal tool for solving issues and problems of enterprises, as there are tasks that can not be entrusted to independent professionals. Any business strategy of the enterprise must be consistent with the probable risks.
\end{abstract}

Key words: outsourcing, outsourcer, business process, types of outsourcing, enterprise management, IT sphere.

JEL Classification: F62, J29, M21

\footnotetext{
Corresponding author:

${ }^{1}$ Dnipro State Agrarian and Economic University, Ukraine.

E-mail: skhalatur@gmail.com

ORCID: https://orcid.org/0000-0001-8331-3341

ResearcherID: T-7645-2019

${ }^{2}$ Odesa National Academy of Food Technologies, Ukraine.

E-mail: k.natali_@ukr.net

ORCID: https://orcid.org/0000-0003-4645-545X

ResearcherID: P-8578-2015

${ }^{3}$ Dnipro State Agrarian and Economic University, Ukraine.

E-mail: kurbatska.l.m@dsau.dp.ua

ORCID: https://orcid.org/0000-0003-2567-3060
} 


\section{Introduction}

In an unstable economy, companies must develop new strategies to maintain their competitive position in the market. The effective functioning of a modern enterprise largely depends on its organizational structure. One of the modern trends in the formation of the optimal structure of the enterprise is its simplification and greater transparency of internal interactions.

Restructuring aimed at improving the efficiency of the enterprise is possible on the basis of the allocation of individual units, including by separating part of the assets of the property complex of the enterprise to create a new entity with efficient business conditions. This process of removing noncore assets and transferring them to a third-party organization is otherwise known as outsourcing. Being only a tool for implementing a business strategy, carefully planned outsourcing can radically change the company's performance, increase its value. Therefore, outsourcing is an effective tool for enterprise restructuring and transformation.

According to a study by Ernst \& Young, outsourcing is practiced by the vast majority of European companies. Thus, $70 \%$ of surveyed managers hire freelancers to perform at least one function, and $20 \%$ plan to increase the number of freelancers in the next two years; $49 \%$ of respondents reported that outsourcing minimizes expenses. Ukrainian companies are reluctant to outsource some operations for fear of losing control of the business. There is a widespread belief that outsourcing is used only for a limited list of functions; its use leads to a reduction in jobs and wages. This mechanism is used mainly by domestic firms with foreign capital, as well as holdings with subsidiaries.

The main objectives of economic development are to improve the overall efficiency of enterprises and to optimize the use of existing opportunities to obtain a sustainable position in the domestic and international markets. The emergence of Internet technologies is shaping new market demands, changes in labor relations, new forms of cooperation and more. The instability of Ukrainian enterprises, due to constant changes in their internal and external environment, requires the introduction of a strategic approach to management. A component of this approach is the use of outsourcing as a way to optimize the overall costs of the enterprise. The studied problem is the lack of theoretical and methodological foundations in the field of strategic decision-making on the transfer of non-core business functions to outsourcing and their economic justification.

Thus, modern business is very dynamic and requires flexibility and rapid response to changes in society. The conditions of market relations formation in Ukraine, which are characterized by the influence of the external environment and increased competition, require the search for innovative means of survival of enterprises and maintaining their efficiency. For this reason, companies not only need to update production and marketing strategies, but also spend a lot of resources on organizing activities. A prerequisite for sustainable economic development is also to ensure the innovation component. In today's global economy, innovation is the basis for the competitiveness of companies, industries and countries. They allow minimal risk to enter into price competition, to win competition for markets and purchases by developing new, more attractive products for consumers or introducing socially-oriented new technologies for the production of existing products and services. Innovative type of development is based on the use of the latest technology, the change of production to a more technologically advanced, modern management and organizational solutions in innovative activities. New industries, centered on high technology and industries that directly meet people's needs, have become fundamental in society. The simultaneous need to form new business strategies of enterprises and the development of outsourcing as a condition for increasing competitiveness in the markets of Europe and Ukraine gives additional impetus to the study of this scientific problem.

The purpose of the article is to substantiate the need for the formation of new business strategies of enterprises and the development of outsourcing as a condition for increasing competitiveness in the markets of Europe and Ukraine.

\section{Literature review}

A significant contribution to the development of business entities and the use of outsourcing in the activities of enterprises is presented in the works of domestic and foreign scientists. Research and development on the application of outsourcing business functions are also implemented in the works of scientists.

Thus, Alla Ivashchenko, Anna Kornyliuk, Yevheniia Polishchuk, Tetiana Romanchenko and Iryna Reshetnikova (2020) studied the implementation of the smart specialization approach in regional strategies. Smart specialization allows the region to be globally competitive. Moreover, smart specialization priorities play a crucial role in creating a network between different regions, even those that are far apart and, at the same time, have much in common to stimulate and foster regional development.

Ola Honningdal Grytten and Viktoriia Koilo (2019) explore the international financial crisis that affected Eastern European economies, the crisis was transferred from Western Europe to international financial 
markets, leading to a liquidity crisis and then a capital crisis, which eventually led to the bankruptcy of the real economy. In addition, fragile political and economic institutions seem to have been unable to resist the development of the crisis. The analysis revealed a significant economic overheating, reflected in the huge expansion of the real economy before the crisis, when the same variables correspondingly declined during the crisis. Thus, the loss of financial stability was an important element of the crisis.

In particular, the paper is consistent with the assertion of Kasperovica, L.; Lace, N. 2021 that in a dynamically changing business environment it is becoming increasingly difficult to identify the factors that influence a company's positive financial performance and, therefore, its sustainable development. These authors have identified the dominant factors that emphasize the importance of supporting a profitable business. The identified factors are divided into groups that affect the financial, non-financial, digital and nondigital areas of activity. The set of identified factors in the interaction creates the conditions for a positive financial result of the business.

\section{Outsourcing as a condition for increasing competitiveness}

According to various estimates, the need for the services of outsourcing companies is more than $\$ 80$ billion a year. In particular, in the European Union, outsourcing services are used by about $45 \%$ of companies. Studies show that outsourcing companies that provide IT services, logistics, marketing, recruitment, bookkeeping, payroll and personnel accounting are the most popular. It should be noted that there are different approaches to defining the concept of "outsourcing", so it is impossible to identify a single subject category and determine its characteristics. It is advisable to define the following types of outsourcing: resource (provision of primary resources), functional (complete control of the outsourcing organization over business functions) and business process outsourcing (control over the interdependent structure of business functions). With a focus on the innovation market, the problem of effective organization and operational management of resource provisioning is a significant challenge. With the help of outsourcing strategies, it becomes possible to minimize the imbalance in the provision and allocation of resources between traditional and innovative activities. In addition, outsourcing makes it possible to solve priority tasks aimed at reducing the duration of the innovation cycle, accelerating the innovation process as a whole, ensuring the earliest possible introduction of innovations into the market.

Figure 1 analyzes the volume of the global market for outsourcing services for the years 2000-2019.

Figure 1 shows the dynamics of the outsourcing services market. Analysis of statistical data shows that interest in outsourcing services increased between 2000 and 2012. In 2013, there was a decline in economic performance in the field of outsourcing, due to changes in the external environment and market conditions. Outsourcing revenue of $\$ 104.6$ billion was the highest in the U.S. in 2014. In 2016, the value of income decreased by $26.5 \%$. Outsourcing revenue is up $13.5 \%$ in 2017 , and experts say growth is projected in the coming years if businesses choose profitable destinations.

Figure 2 shows the growth rate of the global outsourcing market for 2000-2019.

Thus, in the context of globalization, all countries and their businesses are looking for new forms of

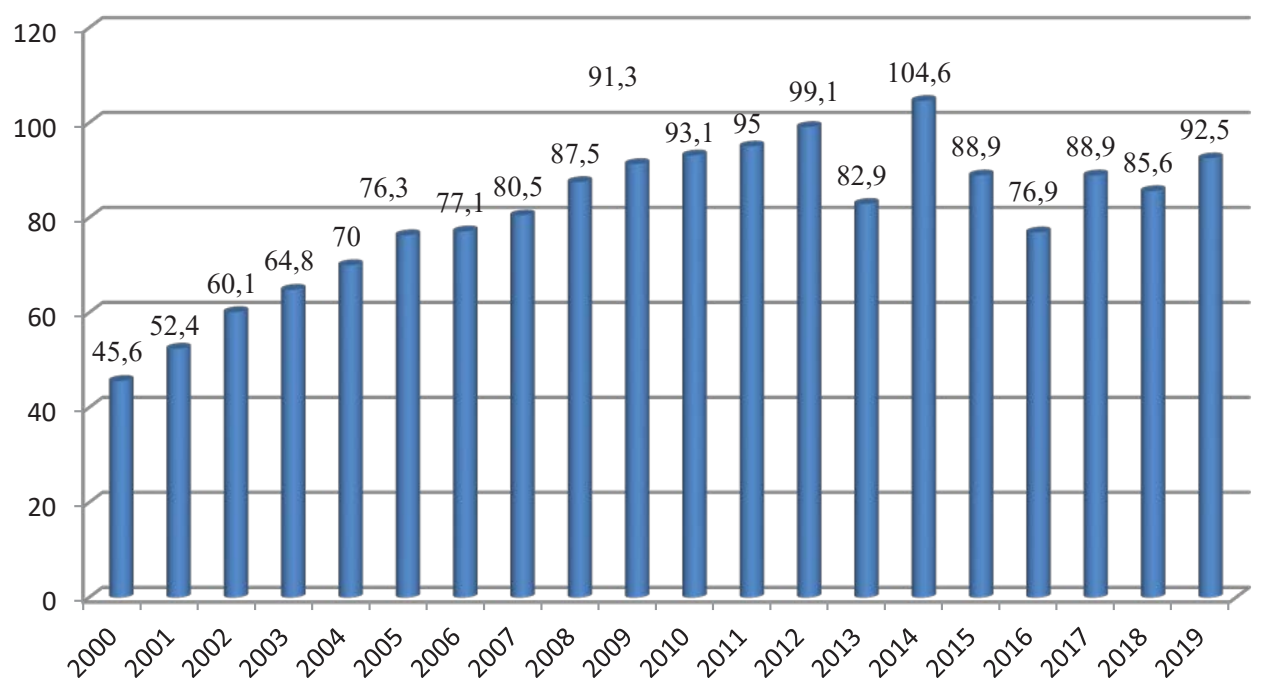

Figure 1. Volume of the global market for outsourcing services in 2000-2019, billion U.S. dollars

Source: compiled by authors based on statistical data 


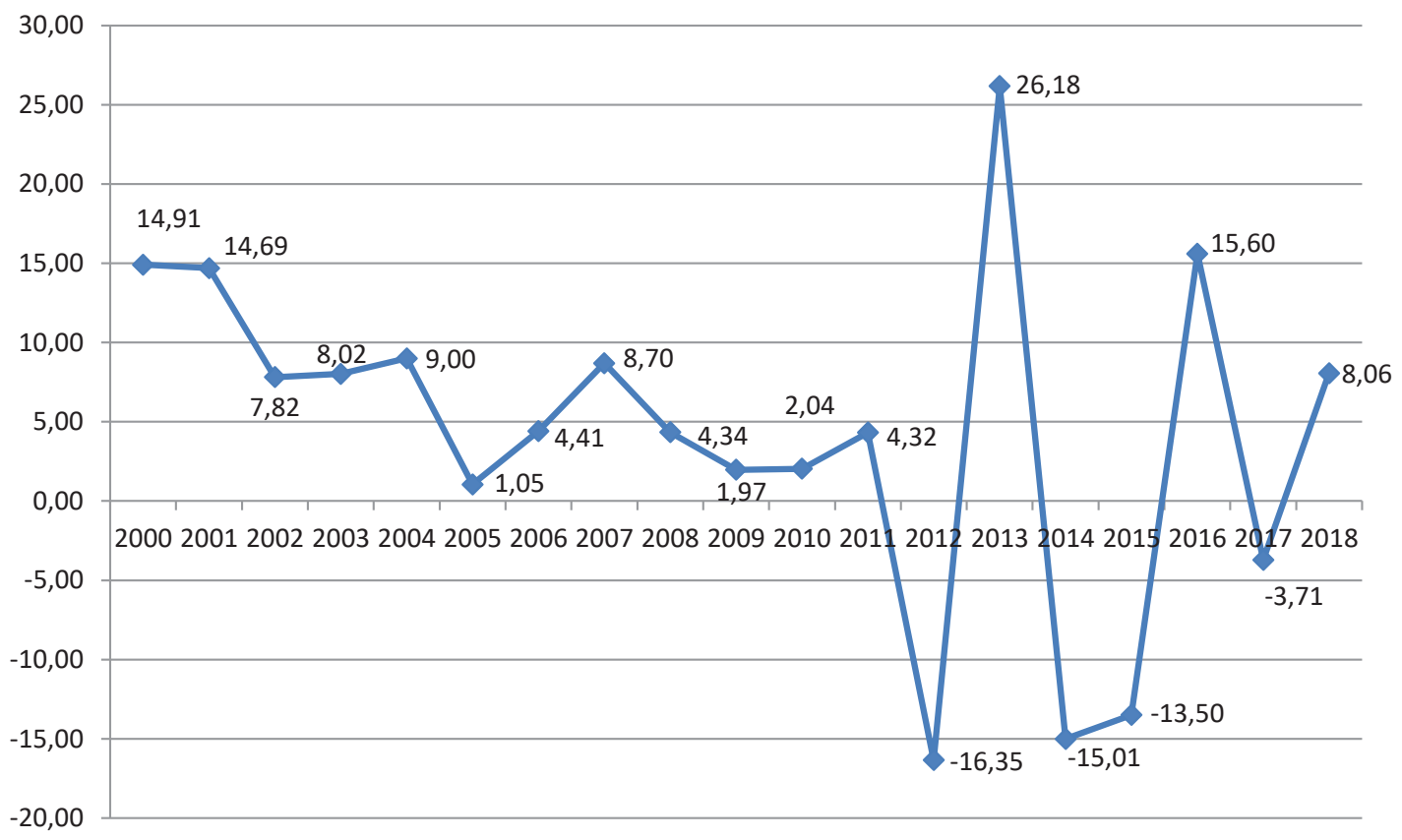

Figure 2. Global Outsourcing Services Market Growth Dynamics 2000-2019, \%

Source: compiled by authors based on statistical data

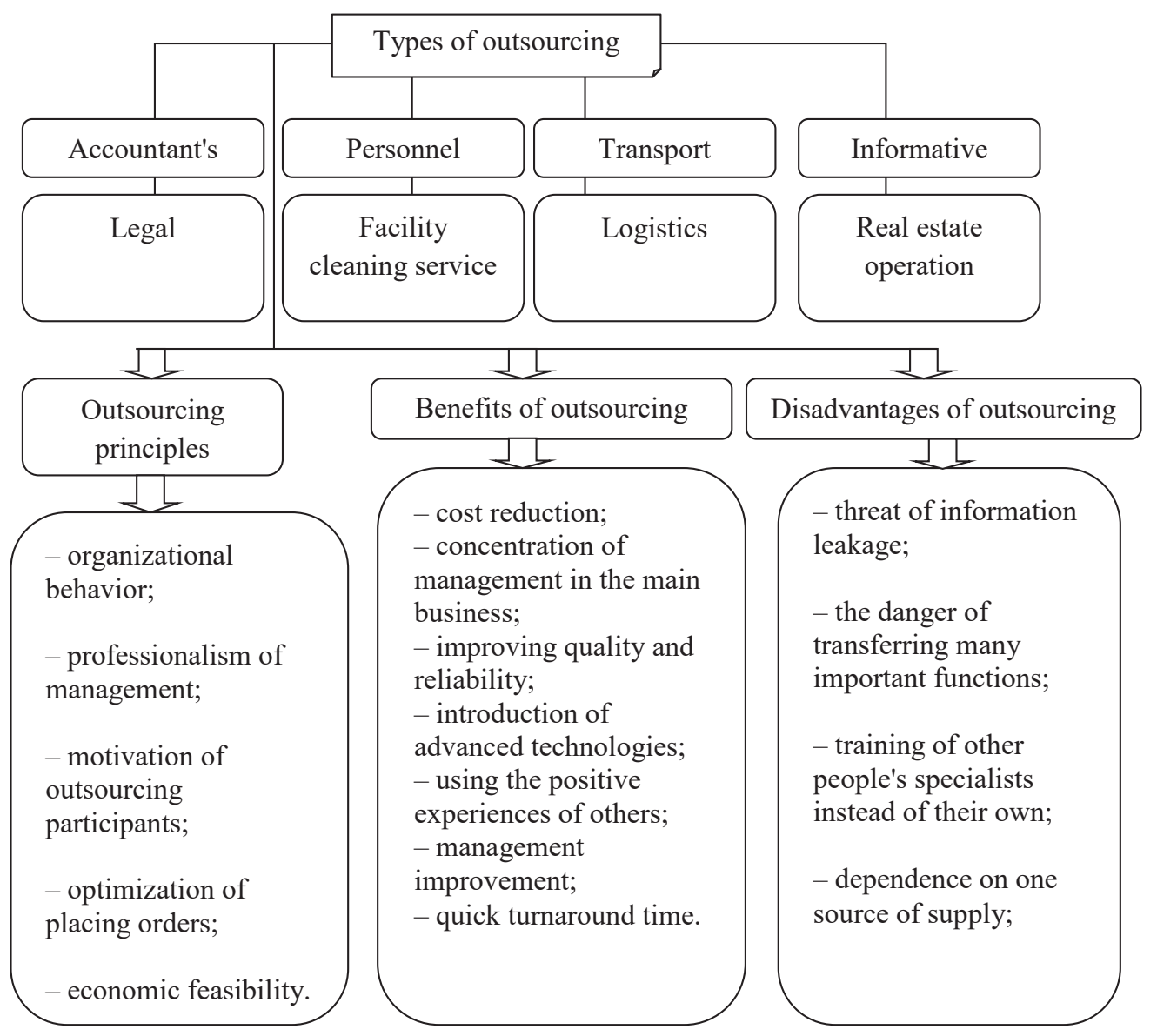

Figure 3. Types, principles, advantages and disadvantages of outsourcing

Source: authors' own development 
international cooperation, including outsourcing. The effectiveness of outsourcing business strategies is confirmed by international practice, which shows that currently more than half of European companies use outsourcing in their activities. There is a unique opportunity for Ukraine and its regions to take advantage of international outsourcing due to the possible positioning in today's market both as a provider of outsourcing services and as a customer. In the first case, this can be achieved through an attractive ratio of high skills and low wages, a satisfactory level of infrastructure development, and in the second case - through access to cheaper or rare resources, new technologies, best business practices, which forms the basis for the transition of Ukrainian enterprises to the innovation path of development.

Experts believe that Ukraine is a strategically important country for outsourcing. Convenient logistics, IT experience and expertise, a relatively cheap labor force and an urgent need to optimize resources form the basis for the sustainable development of outsourcing.

Modern enterprises concentrate their activities on very narrow chains of activity, and other activities are outsourced to independent external contractors. The question of the fundamental need for outsourcing has long been irrelevant in the world, the key importance is only the reliability and professionalism of the partners with whom the contract for certain services is concluded. Transferring the functions of one or more links of the value chain to external partners has a number of strategic advantages: it allows to obtain components or services of higher quality; improves the company's innovation capabilities through interaction and partnership with suppliers who have great intellectual potential and rich innovation experience; provides great flexibility of the company in case of sudden changes in the market situation or consumer preferences; accelerates the acquisition of resources and skills; allows you to focus on those operations that are effectively performed by the company, and those that are strategically appropriate to keep under its control.

The disadvantages of the outsourcing and disintegration strategy are that the company risks taking on too many activities and losing some of its own resources and capabilities. Figure 3 discusses the types, principles, advantages and disadvantages of outsourcing.

Both in Ukraine and in the world clearly distinguish different types of outsourcing with qualitative characteristics. An important factor in effective cooperation in outsourcing is the way in which the outsourcing provider is organized and interacts with it. It is proposed to divide the organizations into: independent, dependent and formally independent outsourcing enterprise. This division is fundamental, based on the fact that each of the allocated types of outsourcing requires drastically different amounts and structure of resources to ensure the activity, on the one hand, and, accordingly, will differ significantly in the distribution of economic results from outsourcing, on the other hand. Also important from the practical point of view of building relations in the system of outsourcing is the area of activity. Outsourcing is divided by the following criteria: complex (dominant), fragmented (individual operations, functions or tasks), functionalconsulting, controlling and regulating. Taking the two criteria for separation as a basis, strategies for the development of outsourcing activities are formed.

Before choosing an outsourcing company, there is an important aspect to consider, namely location, or in other words, the industry landscape of a particular country. However, in all countries there are some commonalities between service providers. You can look at the typical experiences of clients who hire companies in different parts of the world to make a more informed decision. Table 1 lists the top 10 software development outsourcing countries in the world and the challenges for them.

Table 1

10 best countries in the world to develop software for outsourcing in 2021

\begin{tabular}{|c|l|l|}
\hline Ranking & \multicolumn{1}{|c|}{ Country } & \multicolumn{1}{c|}{ Advantages } \\
\hline 1 & Vietnam & $\begin{array}{l}\text { High quality services at low prices, high education level of the population, favorable conditions for doing } \\
\text { business and attracting foreign investment. }\end{array}$ \\
\hline 2 & Philippines & Effective communication (90\% of the population speaks English), technical skills and competence. \\
\hline 3 & Poland & Some of the best programmers in Java, Python, Shell and Ruby. \\
\hline 4 & China & Competence and development opportunities, low development costs. \\
\hline 5 & Taiwan & Resources for education, but there are difficulties in communication (low level of English). \\
\hline 6 & Romania & $\begin{array}{l}\text { Investments in IT development, a lot of qualified engineers, ability to communicate (59\% of Romanians speak } \\
\text { English). }\end{array}$ \\
\hline 7 & Ukraine & Many skilled professionals, especially C ++ programmers. \\
\hline 9 & India & Specialists are fluent in English. \\
\hline 10 & Egypt & Low prices, skilled workers, able to adapt to the needs of customers, no communication problems. \\
\hline
\end{tabular}

Source: compiled by the authors according to the Top Outsourcing Countries. URL: http://www.sour cingline.com 


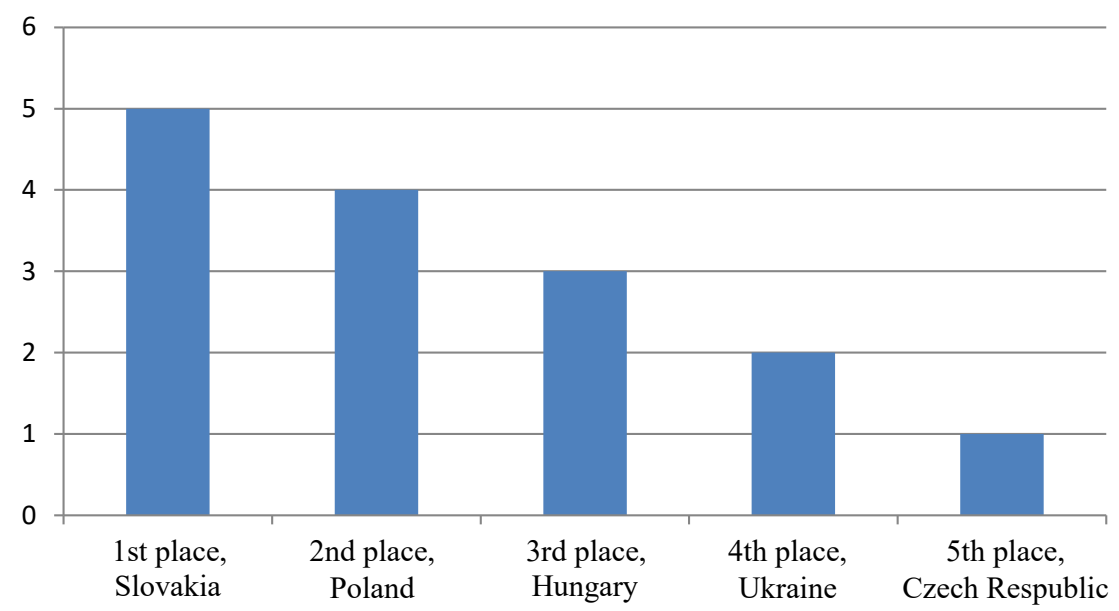

Figure 4 Countries with the best software developers in Europe

Source: Daxx.com, industrytoday.com

According to Table 1, the main characteristics of these countries, contributing to their inclusion in the top 10 outsourcing are: investment in IT development, availability of skilled labor, ability to communicate (knowledge of English at a professional level), convenience of time zones. Figure 4 shows the ranking of countries with the best software developers in Europe.

Poland, a Central European country, like Ukraine, has enormous potential. According to outsourcing statistics, Poland has become the third most experienced programmers in the world. Professionals are fluent in English, and more than 30\% of the country's population uses English as a second language, which is one reason why most companies choose Poland as a place to outsource.

Ukraine, a country in Eastern Europe, has a wide range of educational opportunities and a large number of IT specialists. Ukraine has become the best place for outsourcing and one of the best countries for software outsourcing, especially for web development and software. Ukraine has many professionals who dominate the global software outsourcing market in web and mobile development, machine learning, artificial intelligence and blockchain technologies, with the most popular programming languages being $\mathrm{C}++$, PHP, Java and Ruby. Table 2 shows the features of Ukraine that enable it to enter the world rankings for outsourcing.

Table 3 shows the indicators of the business environment of the European countries studied for an average of 2001-2020.

Ukraine's GDP continues to be relatively low, which is a serious problem of strategic importance for the country. Ukraine needs to increase production and exports of finished products, which will increase GDP in the future. Many factors offset the results of government actions aimed at increasing GDP, among them: the monopoly in the market of important sectors of the economy (alcohol, coal, fuel), corruption, the shadow economy expansion, the war in the East. To overcome all of these problems, significant and effective reforms are needed to help ensure future efficiencies. A comprehensive balanced macroeconomic policy, based on a comprehensive analysis of the dynamics of macroeconomic indicators, will lead the Ukrainian economy out of crisis and improve the socio-economic situation. Equally important are measures to improve the quality and transparency of activities, since, in addition to the basic measures, these ones will help increase the efficiency of budget expenditures, reduce losses from corruption, and improve the quality of public services. Despite considerable natural and human potential, the privatization of much of the country's productive capacity, and the numerous international loans used by the authorities over the past 20 years, Ukraine's production facilities have not been modernized and the industrial facilities have become severely worn out. For the most part, domestic manufacturing products have lost their competitiveness in the international commodity market, and wide domestic demand is largely met by imported goods.

Ukraine's GDP, as a final indicator of economic efficiency, was much lower than in other European countries. This is due to underdeveloped economies, as low value-added countries have been hit harder than others by the weakening of foreign markets. In addition, economic development was constrained by excessive state budget expenditures, which necessitated a strengthening of fiscal policy. Macroeconomic stabilization and restoration of the normal functioning of the banking system should be the priority measures to improve the situation. 
Vol. 7 No. 4, 2021

Table 2

Features of Ukraine, which give it the opportunity to enter the world rankings for outsourcing

\begin{tabular}{|l|l|}
\hline \multicolumn{1}{|c|}{ Feature } & \multicolumn{1}{c|}{ Characteristics } \\
\hline Business environment & $\begin{array}{l}\text { Reforms are underway to create a democratic and transparent country, an efficient banking sector, } \\
\text { and the development of international cooperation. }\end{array}$ \\
\hline Technical skills and mastery & $\begin{array}{l}\text { The largest number of developers specializing in C++ and Unity 3D. The country has the second } \\
\text { highest number of JavaScript, Magento, and Scala software engineers in the world. }\end{array}$ \\
\hline $\begin{array}{l}\text { Large pool of technical talent and } \\
\text { relatively low competition }\end{array}$ & $\begin{array}{l}\text { The Ukrainian technology industry is focused on providing software development services } \\
\text { through small and medium-sized companies. The competition from the world technology giants } \\
\text { is low here, and most specialists work in IT outsourcing. }\end{array}$ \\
\hline $\begin{array}{l}\text { Government support for the IT } \\
\text { industry }\end{array}$ & $\begin{array}{l}\text { IT services exports account for 29\% of the country's total exports and reached } \$ 4.5 \text { billion in } \\
\text { 2019. The Ukrainian government promotes the growth of the IT industry through a low-tax } \\
\text { system. }\end{array}$ \\
\hline Digital transformation & $\begin{array}{l}\text { There are dozens of fintech projects focused on Ukraine, but most development teams support } \\
\text { the EU and U.S. banking sector. }\end{array}$ \\
\hline Cost and quality of life & $\begin{array}{l}\text { The cost of living in Ukraine is much lower than in other European countries. The low cost of } \\
\text { living in Ukraine does not automatically mean a low quality of life. }\end{array}$ \\
\hline $\begin{array}{l}\text { The optimal environment for starting a } \\
\text { business }\end{array}$ & Startups in Ukraine are thriving. \\
\hline Country assets & $\begin{array}{l}\text { Regardless of the political, legal and financial climate emerging in our country, Ukraine has an } \\
\text { excellent geographic location, the largest territory in Europe, abundant natural resources and an } \\
\text { affordable but skilled workforce. }\end{array}$ \\
\hline
\end{tabular}

Source: compiled by the authors on the basis of Official website of Daxx company

Table 3

Indicators of the business environment of the European countries under study, on average for 2001-2020

\begin{tabular}{|l|c|c|c|c|c|c|c|}
\hline \multicolumn{1}{|c|}{ Country } & $\begin{array}{c}\text { Foreign direct } \\
\text { investment, } \\
\text { net inflows } \\
\text { \% of GDP) }\end{array}$ & $\begin{array}{c}\text { Foreign direct } \\
\text { investment, } \\
\text { net outflows } \\
\text { (\% of GDP) }\end{array}$ & $\begin{array}{c}\text { GDP growth } \\
\text { (annual \%) }\end{array}$ & $\begin{array}{c}\text { Gini coefficient } \\
\text { (World Bank } \\
\text { estimate) }\end{array}$ & $\begin{array}{c}\text { Gross capital } \\
\text { formation } \\
\text { \% of GDP) }\end{array}$ & $\begin{array}{c}\text { Inflation, } \\
\text { GDP deflator } \\
\text { (annual \%) }\end{array}$ & $\begin{array}{c}\text { Tax } \\
\text { payments } \\
\text { (number) }\end{array}$ \\
\hline Poland & 3,25 & 1,03 & 3,79 & 33,17 & 20,84 & 2,21 & 23,80 \\
\hline Bulgaria & 8,36 & 0,90 & 3,59 & 36,93 & 24,07 & 4,26 & 16,33 \\
\hline Czech Republic & 4,81 & 1,92 & 2,85 & 26,18 & 28,39 & 1,88 & 10,60 \\
\hline Germany & 2,03 & 3,10 & 1,27 & 30,88 & 20,57 & 1,36 & 10,40 \\
\hline Romania & 3,74 & 0,22 & 4,13 & 36,31 & 25,50 & 10,40 & 62,67 \\
\hline United Kingdom & 4,10 & 3,37 & 1,76 & 34,51 & 17,22 & 1,99 & 8,07 \\
\hline Ukraine & 3,80 & 0,22 & 2,43 & 26,46 & 22,38 & 15,78 & 72,73 \\
\hline Estonia & 8,09 & 3,69 & 3,78 & 32,76 & 29,42 & 4,55 & 7,67 \\
\hline Hungary & 9,80 & 7,63 & 2,56 & 29,87 & 23,68 & 4,32 & 12,33 \\
\hline Latvia & 3,45 & 0,77 & 3,73 & 35,83 & 28,03 & 4,63 & 8,47 \\
\hline Lithuania & 3,14 & 1,17 & 4,22 & 35,83 & 21,34 & 2,92 & 11,07 \\
\hline Portugal & 3,92 & 2,22 & 0,73 & 36,28 & 20,34 & 1,99 & 7,67 \\
\hline Turkey & 1,66 & 0,32 & 4,83 & 40,77 & 26,74 & 13,69 & 10,00 \\
\hline Slovakia & 4,14 & 1,15 & 3,93 & 26,49 & 25,14 & 1,96 & 22,20 \\
\hline France & 2,05 & 3,32 & 1,29 & 32,07 & 22,71 & 1,34 & 11,40 \\
\hline Spain & 2,92 & 4,01 & 1,67 & 34,64 & 23,47 & 1,83 & 8,80 \\
\hline Ireland & 20,21 & 16,51 & 4,76 & 32,54 & 26,17 & 1,69 & 9,00 \\
\hline
\end{tabular}

Source: compiled by authors based on World Bank data

Today Ukraine is not competitive enough on the world stage, which is largely due to the low level of innovation. However, the experience of countries around the world shows that the restructuring of the national economy and the formation of strong competitive advantages become possible only when the country takes the course of development on the basis of innovation. Table 5 analyzes exports of goods and services.
Significant macroeconomic imbalances, the military conflict in eastern Ukraine and the annexation of the Autonomous Republic of Crimea, deep structural imbalances and a lack of transparency in the public sector have led to the need for urgent corrective measures. The first priority should be to ensure macroeconomic stability in the financial sector. This should be accompanied by key structural reforms to accelerate economic growth. Since Ukraine is in a very 
Table 4

The average value of macroeconomic indicators of the EU countries and Ukraine for the period 2001-2020

\begin{tabular}{|c|c|c|c|c|c|c|}
\hline Country & $\begin{array}{c}\text { Ratio of bank } \\
\text { capital to assets } \\
(\%)\end{array}$ & $\begin{array}{c}\text { Claims on } \\
\text { the central } \\
\text { government, etc. } \\
\text { (\% of GDP) }\end{array}$ & $\begin{array}{c}\text { Current account } \\
\text { balance } \\
\text { (\% of GDP) }\end{array}$ & $\begin{array}{l}\text { Imports of goods } \\
\text { and services } \\
\text { (\% of GDP) }\end{array}$ & $\begin{array}{l}\text { Domestic credit } \\
\text { provided } \\
\text { by financial sector } \\
\text { (\% of GDP) }\end{array}$ & $\begin{array}{l}\text { Expenditures } \\
\text { (\% of GDP) }\end{array}$ \\
\hline Austria & 7,71 & 12,22 & 1,74 & 49,33 & 128,37 & 45,04 \\
\hline Belgium & 7,61 & 21,22 & 1,23 & 80,92 & 134,04 & 40,97 \\
\hline Bulgaria & 10,82 & 1,05 & 3,29 & 63,57 & 60,29 & 32,61 \\
\hline Croatia & 13,90 & 16,15 & 2,21 & 46,52 & 87,29 & 39,91 \\
\hline Cyprus & 8,22 & 23,67 & $-4,27$ & 67,70 & 255,57 & 42,65 \\
\hline Czech Republic & 6,54 & 7,18 & 0,35 & 72,20 & 66,82 & 32,96 \\
\hline Denmark & 6,97 & $-3,88$ & 6,96 & 48,14 & 213,60 & 40,44 \\
\hline Estonia & 12,08 & $-3,05$ & 1,67 & 72,86 & 74,34 & 36,34 \\
\hline Finland & 9,30 & 9,12 & $-1,39$ & 37,57 & 155,49 & 39,55 \\
\hline France & 6,52 & 17,65 & $-0,68$ & 30,85 & 147,41 & 47,78 \\
\hline Germany & 6,47 & 8,72 & 7,42 & 40,29 & 134,19 & 28,22 \\
\hline Greece & 10,72 & 13,64 & $-2,86$ & 34,01 & 134,50 & 47,76 \\
\hline Hungary & ---- & 17,76 & 2,23 & 80,56 & 60,28 & 43,49 \\
\hline Ireland & 14,86 & 16,41 & 4,77 & 84,85 & 160,68 & 34,86 \\
\hline Italy & 6,33 & 48,42 & 2,58 & 26,70 & 169,19 & 43,27 \\
\hline Latvia & 9,74 & 2,49 & 1,43 & 61,48 & 57,17 & 43,46 \\
\hline Lithuania & 9,61 & 2,64 & 1,53 & 71,22 & 51,91 & 32,79 \\
\hline Luxembourg & 7,44 & 0,14 & 5,21 & 175,54 & 190,11 & 38,22 \\
\hline Malta & 8,40 & 15,19 & 8,77 & 128,55 & 143,92 & 36,91 \\
\hline Netherlands & 6,21 & 14,43 & 10,84 & 69,33 & 207,17 & 40,95 \\
\hline Poland & 9,77 & 11,18 & $-0,52$ & 48,16 & 73,44 & 34,26 \\
\hline Portugal & 7,04 & 24,75 & 1,38 & 43,44 & 173,76 & 43,76 \\
\hline Romania & 9,34 & 4,97 & $-4,38$ & 43,59 & 37,89 & 33,21 \\
\hline Slovak Republic & 10,45 & 15,49 & $-2,61$ & 90,78 & 72,88 & 40,63 \\
\hline Slovenia & 10,69 & 15,46 & 5,69 & 69,42 & 68,54 & 43,35 \\
\hline Spain & 7,55 & 26,35 & 1,92 & 29,89 & 194,27 & 19,79 \\
\hline Sweden & 6,18 & 3,24 & 3,86 & 41,23 & 154,13 & 33,14 \\
\hline Ukraine & 13,51 & 20,26 & $-3,34$ & 53,81 & 74,35 & 37,37 \\
\hline World & --- & 26,08 & ---- & 29,35 & 132,43 & 27,32 \\
\hline
\end{tabular}

Source: compiled by authors based on World Bank data

difficult political and economic situation, stabilization requires state policy, which must be accompanied by key structural reforms. The government needs to minimize the negative impact of fiscal stabilization on economic activity. In order to do this, it is necessary to: 1) try to find funds for a number of important infrastructure projects, in particular through concessional financing; 2) stimulate entrepreneurial activity as much as possible; 3 ) introduce adequate banking instruments to finance new projects; 4) support export activities as much as possible through information, technical and legal support for exporters themselves, through facilitating the entry of small and medium businesses into foreign markets, and through the formation of an export credit and insurance system. Table 6 shows the average functioning of the tax system of the EU and Ukraine for the period 2001-2020.

Thus, it can be argued that in the search for an optimal tax policy should not copy the experience of individual countries, without taking into account the specifics of the national economy. Any innovations in national legislation should be based on the studied systems of taxation of countries with developed market economies and a thorough analysis of the feasibility and possibility of their application in national tax legislation.

Despite the positive factors, there are a number of problems in Ukraine, which, according to experts, may lead to a significant slowdown in the growth of the outsourcing market. Weak protection of investor rights, unclear tax rules, and the lack of effective copyright laws all make it difficult not only for outsourcers, but for any company. In Ukraine, the main obstacles to the development of outsourcing are the lack of state support, the difficulty of monitoring the outsourcer, the unpredictability of its economic situation and so on. One of the main obstacles is the unreliability of partnership relations. The problems of outsourcing development also include high competition in the market. Companies that work solely as contractors run the risk of remaining uncompetitive. Now outsourcing 
Vol. 7 No. 4, 2021

Table 5

Exports of goods and services, \% of GDP

\begin{tabular}{|c|c|c|c|c|c|c|c|c|}
\hline Country & 2005 & 2014 & 2015 & 2016 & 2017 & 2018 & 2019 & \begin{tabular}{|c|} 
Ratio of \\
2019 to 2005 \\
\end{tabular} \\
\hline The USA & 10,01 & 13,54 & 12,44 & 11,87 & 12,09 & 12,22 & 13,54 & 135,28 \\
\hline Japan & 14,01 & 17,54 & 17,61 & 16,25 & 17,77 & 18,45 & 15,92 & 113,58 \\
\hline China & 33,83 & 23,59 & 21,44 & 19,75 & 19,96 & 19,51 & 24,60 & 72,71 \\
\hline Austria & 48,62 & 53,39 & 53,09 & 52,45 & 54,04 & 55,76 & 53,44 & 109,92 \\
\hline Belgium & 74,28 & 79,80 & 77,81 & 79,38 & 82,31 & 82,58 & 79,32 & 106,79 \\
\hline Bulgaria & 42,86 & 64,90 & 64,54 & 64,73 & 68,15 & 66,94 & 64,88 & 151,36 \\
\hline Croatia & 36,73 & 43,30 & 46,38 & 47,63 & 50,03 & 50,52 & 40,43 & 110,09 \\
\hline Cyprus & 55,69 & 66,11 & 70,33 & 70,75 & 73,02 & 73,07 & 61,36 & 110,18 \\
\hline Czech Republic & 62,18 & 82,55 & 81,05 & 79,56 & 79,73 & 78,39 & 76,87 & 123,62 \\
\hline Denmark & 47,45 & 54,61 & 55,42 & 53,43 & 55,14 & 55,64 & 54,83 & 115,55 \\
\hline Estonia & 65,47 & 81,33 & 76,87 & 77,45 & 76,14 & 74,26 & 84,02 & 128,33 \\
\hline Finland & 40,27 & 36,48 & 35,39 & 34,82 & 37,68 & 38,56 & 38,02 & 94,40 \\
\hline France & 27,03 & 29,67 & 30,59 & 30,25 & 30,82 & 31,34 & 29,36 & 108,63 \\
\hline Germany & 38,06 & 45,62 & 46,85 & 46,02 & 47,40 & 47,42 & 45,42 & 119,34 \\
\hline Greece & 21,31 & 32,37 & 31,55 & 30,06 & 32,99 & 36,13 & 30,35 & 142,42 \\
\hline Hungary & 62,64 & 87,42 & 87,98 & 87,15 & 87,14 & 84,94 & 85,58 & 136,62 \\
\hline Ireland & 79,58 & 110,03 & 121,97 & 120,82 & 121,04 & 122,33 & 103,66 & 130,26 \\
\hline Italy & 24,60 & 29,11 & 29,72 & 29,33 & 30,84 & 31,45 & 28,63 & 116,39 \\
\hline Latvia & 43,21 & 61,20 & 60,72 & 60,40 & 62,13 & 61,30 & 60,26 & 139,46 \\
\hline Lithuania & 53,84 & 72,34 & 68,82 & 67,58 & 73,61 & 75,62 & 78,79 & 146,34 \\
\hline Luxembourg & 161,68 & 212,61 & 221,20 & 213,04 & 217,62 & 211,56 & 190,63 & 117,91 \\
\hline Malta & 104,37 & 148,85 & 153,77 & 151,90 & 149,77 & 144,87 & 156,98 & 150,41 \\
\hline Netherlands & 65,63 & 80,58 & 82,66 & 79,54 & 83,39 & 84,32 & 79,88 & 121,71 \\
\hline Poland & 34,61 & 47,57 & 49,50 & 52,19 & 54,35 & 55,59 & 46,32 & 133,83 \\
\hline Portugal & 27,08 & 40,22 & 40,62 & 40,21 & 42,72 & 43,52 & 39,61 & 146,23 \\
\hline Romania & 24,54 & 41,16 & 41,02 & 41,19 & 41,47 & 41,64 & 39,87 & 162,51 \\
\hline Slovak Republic & 72,30 & 91,52 & 92,02 & 93,73 & 95,11 & 96,09 & 93,62 & 129,48 \\
\hline Slovenia & 59,81 & 76,15 & 77,15 & 77,97 & 83,17 & 85,38 & 74,22 & 124,08 \\
\hline Spain & 24,98 & 33,48 & 33,63 & 33,88 & 35,18 & 35,12 & 32,96 & 131,96 \\
\hline Sweden & 45,05 & 43,57 & 44,29 & 43,26 & 44,43 & 45,79 & 42,80 & 95,01 \\
\hline Ukraine & 48,75 & 48,59 & 52,60 & 49,30 & 48,01 & 45,21 & 42,96 & 88,12 \\
\hline World & 28,64 & 30,18 & 29,31 & 28,46 & 29,43 & 30,11 & 30,40 & 106,14 \\
\hline
\end{tabular}

Source: compiled by authors based on World Bank data

companies are increasingly seeking to expand the range of their services, additionally offering consulting services, marketing and project management to optimize costs. According to experts working in the outsourcing market, unique services are what can allow a modern outsourcing company to survive in this market. In addition, these services must be in an area that cannot be automated. According to experts, every fourth workplace created in business process outsourcing is automated. Today, more than 1 million jobs in major outsourcing countries are threatened by automation.

\section{Conclusions}

The above provisions on the practical application and features of outsourcing in Ukraine and European countries require further study and elaboration. Outsourcing is an effective way of doing business, given the benefits and opportunities that the customer company receives when using it. The business model of innovative outsourcing is an important direction of modern business development in the global marketplace. Nowadays, personnel outsourcing is an effective tool for improving the performance of any enterprise, taking into account the above-mentioned advantages and limitations that the client company receives when applying them. However, outsourcing should not be considered as a universal tool for solving the issues and problems of enterprises, because there are tasks that cannot be entrusted to independent professionals. Any business strategy of the enterprise must be consistent with the probable risks. Rather frequent use of outsourcing can create additional difficulties. It should also be noted that the abovementioned innovative personnel management tools require a review of their content and feasibility in accordance with the current legislation of Ukraine. At the present stage, outsourcing plays a very important role in improving the efficiency 
Table 6

The average operation cost of the EU and Ukrainian tax system for the period 2001-2020

\begin{tabular}{|c|c|c|c|c|c|c|}
\hline Country & $\begin{array}{c}\text { Labor tax and } \\
\text { contributions ( } \% \text { of } \\
\text { commercial profits) }\end{array}$ & $\begin{array}{l}\text { Other taxes } \\
\text { (\% of revenue) }\end{array}$ & $\begin{array}{c}\text { Profit tax } \\
\text { (\% of commercial } \\
\text { profits) }\end{array}$ & $\begin{array}{l}\text { Tax payments } \\
\text { (number) }\end{array}$ & $\begin{array}{l}\text { Tax revenues } \\
(\% \text { of GDP) }\end{array}$ & $\begin{array}{c}\text { Taxes on goods } \\
\text { and services } \\
\text { (\% of revenue) }\end{array}$ \\
\hline Austria & 34,41 & 3,93 & 16,86 & 12,00 & 26,01 & 27,18 \\
\hline Belgium & 48,55 & 0,50 & 8,50 & 11,00 & 25,02 & 25,08 \\
\hline Bulgaria & 23,24 & 0,16 & 5,19 & 16,33 & 19,67 & 44,42 \\
\hline Croatia & 19,11 & 0,74 & 0,00 & 24,93 & 20,73 & 46,25 \\
\hline Cyprus & 12,37 & 4,85 & 8,78 & 27,83 & 31,57 & 35,02 \\
\hline Czech Republic & 38,77 & 0,14 & 5,60 & 10,60 & 14,44 & 28,50 \\
\hline Denmark & 3,11 & 4,56 & 20,84 & 10,00 & 32,84 & 37,84 \\
\hline Estonia & 38,79 & - & 8,58 & 7,67 & 20,14 & 36,24 \\
\hline Finland & 26,09 & 0,79 & 14,65 & 11,20 & 20,82 & 36,38 \\
\hline France & 51,82 & 4,26 & 4,37 & 11,40 & 22,63 & 23,36 \\
\hline Germany & 21,68 & - & 22,06 & 10,40 & 11,22 & 23,37 \\
\hline Greece & 30,58 & 2,99 & 17,54 & 10,20 & 22,21 & 31,39 \\
\hline Hungary & 35,47 & 1,09 & 10,17 & 12,33 & 21,89 & 35,97 \\
\hline Ireland & 12,13 & 2,01 & 12,15 & 9,00 & 22,64 & 34,41 \\
\hline Italy & 41,52 & 5,01 & 23,06 & 13,80 & 22,35 & 22,79 \\
\hline Latvia & 27,05 & 0,47 & 6,27 & 8,47 & 21,24 & 41,00 \\
\hline Lithuania & 35,17 & 0,24 & 6,47 & 11,07 & 17,87 & 34,07 \\
\hline Luxembourg & 15,44 & 2,09 & 4,32 & 23,00 & 25,02 & 30,45 \\
\hline Malta & 10,84 & 0,57 & 31,16 & 7,44 & 38,43 & 35,45 \\
\hline Norway & 15,90 & 0,51 & 23,91 & 4,13 & 25,94 & 25,16 \\
\hline Poland & 25,15 & 0,73 & 15,05 & 23,80 & 16,49 & 35,82 \\
\hline Romania & 29,81 & 0,17 & 11,61 & 62,67 & 17,21 & 36,26 \\
\hline Slovak Republic & 39,65 & 0,06 & 8,38 & 22,20 & 16,62 & 30,10 \\
\hline Slovenia & 19,41 & 1,79 & 13,74 & 15,33 & 19,22 & 35,36 \\
\hline Spain & 35,55 & 0,19 & 15,75 & 8,80 & 14,25 & 43,37 \\
\hline Sweden & 35,81 & 29,75 & 15,07 & 6,00 & 27,05 & 37,26 \\
\hline Ukraine & 40,57 & $-0,01$ & 11,17 & 72,73 & 16,96 & 32,98 \\
\hline United Kingdom & 11,16 & 5,38 & 20,71 & 8,07 & 25,12 & 32,34 \\
\hline
\end{tabular}

Source: compiled by authors based on World Bank data

of the company by transferring not only some functions, but often also business processes to external organizations to optimize the use of all resources and to focus on one type of activity.

The final choice of strategy should be made by analyzing additional criteria and indicators, namely: the structure and level of possible losses, access to limited resources, the size of the enterprise and the type of economic activity, changes in competition in the industry and market segments, financial performance, the probability and magnitude of risks before and after the outsourcing agreement, the propensity to risk of the dominant stakeholders and managers and owners, connection with other types of interaction between counterparties, trends and tendencies in the environment, resource potential and its structure.

\section{References:}

Dagilienė, L., Bruneckienė, J., Jucevičius, R., \& Lukauskas, M. (2020). Exploring smart economic development and competitiveness in Central and Eastern European countries. Competitiveness Review, 30(5), $485-505$. DOI: http://dx.doi. org/10.1108/cr-04-2019-0041

Industry Today, media platform. Available at: DOI: https://industrytoday.com/top-5-countries-foroutsourcing-in-2021/

Ivashchenko, A., Kornyliuk, A., Polishchuk, Y., Romanchenko, T., \& Reshetnikova, I. (2020). Regional smart specialization in Ukraine: JRC methodology applicability. Problems and Perspectives in Management, 18(4), 247-263. DOI: https://doi.org/10.21511/ppm.18(4).2020.21

Kasperovica, L., \& Lace, N. (2021). Factors influencing companies' positive financial performance in digital age: a meta-analysis. Entrepreneurship and Sustainability Issues, 8(4), 291-311. DOI: https://doi.org/10.9770/ jesi.2021.8.4(17) 
Khalatur, S. M., \& Hudym, K. M. (2016). Systematization and analyze of TNCs' conduct model during coming into the national agrarian markets. Economic Annals - XXI, 159(5-6), 34-37.

Khalatur, S. (2017). Important provisions for the development of agriculture of Ukraine. Baltic Journal of Economic Studies, 3(2), 147-154. DOI: https://doi.org/10.30525/2256-0742/2017-3-2-147-154

Khalatur, S., Trokhymets, O., \& Karamushka, O. (2020). Conceptual basis of tax policy formation in the globalization conditions. Baltic Journal of Economic Studies, 6(2), 81-92. DOI: https://doi.org/10.30525/22560742/2020-6-2-81-92

Khalatur, S., Khaminich, S., Dubovych, O., Budko, O., \& Karamushka, O. (2020). Multiple system of innovation investment decisions adoption with synergetic approach usage. Entrepreneurship and Sustainability, 7(4), 2745-2763. DOI: http://doi.org/10.9770/jesi.2020.7.4(12)

Khalatur, S., Kriuchko, L., \& Sirko, A. (2020). World experience adaptation of anti-crisis management of enterprises in the conditions of national economy's transformation. Baltic Journal of Economic Studies, 6(3), 171-182. DOI: https://doi.org/10.30525/2256-0742/2020-6-3-171-182

Khalatur, S., Vinichenko, I., \& Volovyk, D. (2021). Development of modern business processes and outsourcing activities. Baltic Journal of Economic Studies, 7(3), 195-202. DOI: https://doi.org/10.30525/2256-07429 2021-7-3-195-202

Official website of Daxx company. Available at: https://www.daxx.com/blog/development-trends/best-offshoredevelopment-countries-2021

Ola Honningdal Grytten and Viktoriia Koilo (2019). Financial instability, institutional development and economic crisis in Eastern Europe. Investment Management and Financial Innovations, 16(3), $167-181$. DOI: https://doi.org/10.21511/imfi.16(3).2019.16

The Outsourcing Institute, USA. Available at: http://www.outsourcing.com

Global Outsourcing market 2020. Available at: https://www.statista.com/statistics/189788/global-outsourcingmarket-size

Statista data 2021. Available at: https://www.statista.com/statistics/189800/global-outsourcing-industryrevenue-by-service-type/

Top Outsourcing Countries. Available at: http://www.sourcingline.com/top-outsourcing-countries?order=field cp2010 overall rank value\&sort=desc. 9

Vasylieva, N. (2019). Improvement of Agricultural Management: Functional Comparative Approach. Montenegrin Journal of Economics, 15(1), 227-238. DOI: https://doi.org/10.14254/1800-5845/2019.15-1.17

Velychko, O., Velychko, L., \& Ramanauskas, J. (2016). Transformation and development of production-logistics enterprises in Ukrainian agrarian economy. Management Theory and Studies for Rural Business and Infrastructure Development, 38(1), 70-87. DOI: https://doi.org/10.15544/mts.2016.7

World Bank (2021). World Development Indicators 2021, World Bank. Available at: https://data.worldbank.org/ indicator (accessed 11 May 2021). 